\title{
PENGEMBANGAN VIDEO PEMBELAJARAN MATEMATIKA DENGAN MENGGUNAKAN APLIKASI GEOGEBRA PADA MATERI BANGUN RUANG SISI DATAR KELAS VIII SEKOLAH MENENGAH PERTAMA
}

\author{
Jelita Kusria', Hera Deswita ${ }^{2}$ \\ 1,2 Universitas Pasir Pengaraian \\ anjelitaweet14@gmail.com
}

\begin{abstract}
Students in this digital era need the use of video in learning geometry. The video used should be able to foster students' understanding of the material. Learning geometry requires simulation and animation to find the concept. One application that can provide a representative appearance of geometric material is GeoGebra. Thus a learning video is needed using the GeoGebra application. This study aimed to develop a mathematics learning video using GeoGebra applications on the flat side room building material of class VIII SMP. This research is development research. This mathematics learning video development uses a 3-D development stage consisting of three stages: the Define stage, the Design stage, and the Development stage. The research results that have been validated by two validators show that the product in the form of a mathematics learning video is very valid so that it is suitable for use by junior high school students and teachers of mathematics subjects. This learning video contains an explanation of the flat side room building material for class VIII SMP. From the validation, it was obtained that the overall average aspect of the assessment was 3.6 in the Very Valid category.
\end{abstract}

Keywords: Learning Videos, Geometry, GeoGebra

\begin{abstract}
ABSTRAK Siswa di era digital membutuhkan penggunaan video dalam pembelajaran geometri. Video yang digunakan harus dapat menumbuhkan pemahaman siswa terhadap materi. Belajar geometri membutuhkan simulasi dan animasi untuk menemukan konsepnya. Salah satu aplikasi yang dapat memberikan tampilan representatif dari material geometris adalah GeoGebra. Oleh karena itu diperlukan video pembelajaran dengan menggunakan aplikasi GeoGebra. Penelitian ini bertujuan untuk mengembangkan video pembelajaran matematika menggunakan aplikasi GeoGebra pada materi bangunan ruang sisi datar siswa kelas VIII SMP. Penelitian ini merupakan penelitian pengembangan. Pengembangan video pembelajaran matematika ini menggunakan tahap pengembangan 3 dimensi yang terdiri dari tiga tahap yaitu tahap Define, tahap Design, dan tahap Development. Hasil penelitian yang telah divalidasi oleh dua validator menunjukkan bahwa produk berupa video pembelajaran matematika sangat valid sehingga layak digunakan oleh siswa sekolah menengah pertama dan guru mata pelajaran matematika. Video pembelajaran ini berisi tentang penjelasan materi bangunan ruang sisi datar untuk siswa kelas VIII SMP. Dari hasil validasi diperoleh rata-rata keseluruhan aspek penilaian adalah 3,6 dengan kategori Sangat Valid.
\end{abstract}

Kata-kata Kunci : Video Pembelajaran, Bangun Ruang Sisi Datar, GeoGebra 


\section{PENDAHULUAN}

Era digital adalah masa dimana semua orang menggunakan media elektronik dalam kegiatan sehari-hari. Bukan hanya orang dewasa saja yang menggunakannya, namun banyak anak-anak sekolah yang juga menggunakan peralatan tersebut, baik siswa Sekolah Menengah Atas (SMA), sekolah Menengah Pertama (SMP) bahkan siswa Sekolah Dasar (SD) saja sudah menggunakan peralatan elektronik tersebut, khususnya peralatan yang berbentuk Smartphone dan komputer. Mereka menggunakan smartphone dan komputer ini untuk berbagai hal, ada yang menggunakannya untuk berbisnis, berniaga, untuk berkomunikasi dengan keluarga yang jauh, dan menggunakannya sebagai alat perantara mencari referensi tugas dan mencari informasi-informasi. Fasilitas-fasilitas yang terdapat dalam smartphone dan komputer dapat digunakan sebagai sarana pembelajaran dimana melalui alat tersebut seseorang dapat mempelajari hal-hal baru melalui isi atau pesan yang disalurkan. Selain itu smartphone dan komputer juga digunakan masyarakat sebagai salah satu gaya hidup. Menurut Kotler dalam Daeng (2017) adalah pola hidup seseorang di dunia yang diekspresikan dalam aktivitas, minat, dan opininya. Jadi, smartphone dan komputer juga bisa menjadi media hiburan sekaligus menyalurkan hobi seseorang seperti; bermain game dan mendengarkan musik bahkan kita dapat bermain alat musik dengan menggunakan aplikasi-aplikasi pendukung. Selain itu, smartphone dan komputer dapat menjadi sarana untuk menjalankan bisnis (bisnis yang berbasis on-line) dan dapat menjadi alat untuk menyimpan berbagai macam data baik dalam bentuk huruf, angka dan gambar.

Pada hakikatnya teknologi diciptakan agar dapat mempermudah manusia dalam beraktivitas serta memberikan kenyamanan bagi penggunanya. Perkembangan zaman yang semakin modern menciptakan berbagai macam teknologi yang semakin canggih sehingga membuat hampir tidak ada bidang kehidupan manusia yang bebas dari penggunaannya khususnya teknologi komunikasi yang saat ini mampu memberikan transformasi bagi kehidupan manusia. Tidak hanya itu saja, pembelajaran zaman sekarang juga menggunakan banyak teknologi, di dunia pendidikan, peralatan teknologi yang canggih digunakan sebagai sarana prasarana dalam pembelajaran, karena banyak kemudahan-kemudahan yang diperoleh dari penggunaannya. Kemudahan yang diperoleh dari pemanfaatan teknologi seperti berkembang pesat kursus online yang memungkinkan kita tidak perlu menghadiri kelas secara fisik, kita hanya perlu menyediakan waktu kapan saja untuk menyimak penjelasan dari guru dan mentor melalui video. Tidak hanya itu, Jamil (2019) menyatakan manfaat yang diperoleh dalam penggunaan komputer dalam pendidikan dapat dijadikan seperti kertas, pensil, buku, video dan lain sebagainya. Dalam beberapa mata pelajaran tertentu komputer dapat membantu belajar menjadi lebih efektif. Komputer dapat berperan besar dalam pembelajaran jika digunakan secara semestinya. Komputer dapat membantu pendidik dalam memudahkan pembelajaran, bahkan dapat memotivasi dan mengakselerasi belajar siswa. Tapi komputer dapat juga menjadikan pendidik seperti robot dan sangat mekanis, serta menjadikan siswa seperti makhluk asing yang kurang memiliki skill sosial. Ada beberapa factor yang menjadikan seseorang menjadi manusia mekanis karena 
teknologi komputer dalam dunia pendidikan dan pembelajaran. Menurut Sudjana dan Rivai dalam Efendi (2018) ada beberapa model pembelajaran dengan komputer, yaitu model latihan dan praktek (drill and practice), model tutorial (tutorials), model penemuan (problem solving), model simulasi (simulations), dan model permainan (game). Model pembelajaran ini dapat digunakan pendidik dalam kegiatan pembelajaran agar pembelajaran lebih menarik sehingga dapat membantu peserta didik untuk mengembangkan pengetahuan mereka.

Zaman dahulu murid lebih sering menghafal buku, guru menerangkan dan murid mendengarkan, oleh karena itu, guru selalu lebih tahu dari murid. Zaman dulu murid tidak berani membantah guru. Sementara murid zaman sekarang banyak yang berakhlak buruk. Selain itu, murid zaman sekarang banyak yang lebih tahu daripada gurunya, karena banyak informasi yang bisa dicari melalui internet melalui peralatan teknologi. Dengan perkembangan teknologi di zaman sekarang, anak dapat belajar di mana saja dan gurupun dapat menjadi fasilitator dan moderator pembelajaran tanpa terikat ruang fisik. Saat ini masyarakat termasuk para guru sudah memasuki era digital, yaitu suatu era yang sudah melampaui era teknologi komputer.

Murid zaman sekarang terkadang sangat susah memahami pelajaran, terkhususnya pelajaran bangun ruang sisi datar untuk kelas VIII Sekolah Menengah Pertama. Dari hasil wawancara penulis kepada guru dan murid kelas VIII SMP LPMD Suka Maju Rambah, materi bangun ruang sisi datar susah dipahami karena bentuk bangun yang tidak bisa mereka imajinasikan, mereka tidak bisa menebak apa-apa saja dan bagaimana bentuk dari unsur-unsur bangun ruang sisi datar tersebut. Oleh sebab itu, penulis berinisiatif untuk membuat video pembelajaran matematika dalam sebuah penelitian, yang bisa mereka pelajari agar mudah memahami bangun ruang sisi datar, karena di dalam video tersebut ditunjukkan apa-apa saja unsur-unsur dari bangun ruang sisi datar, dan ada juga penjelasan tentang jaring-jaring bangun ruang sisi datar serta penjelasan tentang luas dan volume bangun ruang sisi datar tersebut. Bangun ruang sisi datar merupakan salah satu materi pembelajaran matematika kelas VIII Sekolah Menengah Pertama pada semester genap, bangun ruang sisi datar adalah bangun ruang yang memiliki sisi berbentuk datar (bukan sisi lengkung) dan memiliki volume atau isi. Bangun ruang sisi datar meliputi kubus, balok, prisma, dan limas.

Saat ini, seorang pendidik harus mampu membuat dan memilih media pembelajaran yang menarik dan variatif agar mampu menyampaikan materi atau bahan ajar dengan baik, membuat media yang sesuai dengan bahan ajar agar siswa mampu memahami materi melaui media yang disiapkan. Meskipun demikian, dapat dikatakan bahwa salah satu fungsi utama media pembelajaran adalah sebagai alat bantu mengajar yang turut mempengaruhi iklim, kondisi dan lingkungan belajar yang ditata dan diciptakan oleh tenaga pendidik. Adapun manfaat yang akan diperoleh dari penggunaan media pembelajaran, sebagaimana dikemukakan oleh Sudjana dalam Negari (2012) yaitu:

1. Pembelajaran akan lebih menarik perhatian peserta didik sehingga dapat menumbuhkan motivasi belajar. 
2. Metode pembelajaran akan lebih bervariasi, tidak semata-mata komunikasi verbal melalui penuturan oleh guru, sehingga peserta didik tidak bosan dan guru tidak kehabisan tenaga, apabila guru harus mengajar untuk setiap jam pelajaran.

3. Bahan pembelajaran akan lebih jelas maknanya sehingga lebih dipahami oleh peserta didik dan memungkinkan peserta didik menguasai tujuan pembelajaran lebih baik.

4. Peserta didik lebih banyak melakukan kegiatan belajar, sebab tidak hanya mendengarkan uraian guru, tetapi juga aktivitas lain seperti mengamati, melakukan, mendemonstrasikan dan lain-lain.

Berdasarkan manfaat yang diperoleh dari penggunaan media pembelajaran di atas, untuk menciptakan pembelajaran yang menarik dan memudahkan belajar siswa sehingga mampu membangkitkan semangat belajar. Terdapat banyak alternatif, antara lain dengan melengkapi sarana dan prasarana pembelajaran, serta diperkaya oleh sumber-sumber belajar yang memadai, juga didukung dengan inovasi media pembelajaran. Inovasi media pembelajaran tersebut digunakan untuk meningkatkan kualitas pembelajaran. Beberapa produk teknologi yang dapat digunakan sebagai inovasi dalam pembelajaran adalah komputer dan smartphone.

Berdasarkan hasil wawancara dengan guru matematika dan siswa kelas VIII salah satu SMP yang ada di Rambah, ada beberapa penyebab kesulitan siswa dalam memahami bangun ruang sisi datar. Pertama, kurangnya minat siswa dalam mempelajari Matematika, sehingga pelajaran apapun yang ada pada matematika menjadi susah dipahami; Kedua, untuk mempelajari bangun ruang, siswa tidak bisa berimajinasi bagaimana bentuk ruang yang ada dalam bangun ruang tersebut; Ketiga, media pembelajaran yang minim, membuat siswa susah memahami bagaimana bentuk luar dan dalam dari bangun ruang, karena siswa tidak bisa menunjukkan langsung pada media tersebut mana yang rusuk, titik sudut, diagonal bidang, diagonal ruang maupun bidang diagonal. Oleh sebab itu, ada baiknya pada pembelajaran di masa sekarang siswa diarahkan untuk mampu menggunakan teknologi, seperti melihat isi video pembelajaran pada smartphone atau alat pemutar Compact Disc (CD).

GeoGebra adalah salah satu aplikasi yang bisa digunakan untuk meningkatkan semangat belajar dan kemampuan siswa dalam memahami materi bangun ruang. GeoGebra merupakan program dinamis yang beragam fasilitasnya dapat dimanfaatkan sebagai media pembelajaran matematika. Selain itu, GeoGebra juga dapat digunakan untuk mendemonstrasikan atau memvisualisasikan konsep-konsep matematis serta alat bantu untuk mengkonstruksi konsep-konsep tersebut. Dengan program GeoGebra, objek-objek matematika yang bersifat abstrak dapat divisualisasi sekaligus dapat dimanipulasi secara cepat dan efisien. Di SMP salah satu pelajaran yang cenderung abstrak adalah matematika. Salah satu bagian dari matematika yang bersifat abstrak adalah geometri. Menurut Aliviah (2012) selama ini pembelajaran geometri di kelas tersebut hanya diajarkan menggunakan media papan tulis dan belum memanfaatkan media pembelajaran seperti komputer. 
Penyampaian materi yang sering dilakukan guru adalah berupa pembelajaran konvensional seperti ceramah, sehingga ada siswa yang mengalami kesulitan untuk memahami materi yang disampaikan. Untuk itu dibutuhkan media lain yang dapat membantu pemahaman siswa mengenai geometri tersebut. Dengan komponen komputer dan menggunakan aplikasi GeoGebra bisa diciptakan video pembelajaran yang diharapkan mampu membuat media pembelajaran matematika pada materi bangun ruang agar lebih mudah dipahami.

\section{METODE PENELITIAN}

Jenis penelitian ini adalah penelitian pengembangan. Penelitian pengembangan digunakan untuk menghasilkan dan mengembangkan produk tertentu dan menguji kualitas produk tersebut. Untuk menghasilkan produk tertentu digunakan penelitian yang bersifat analisis kebutuhan dan untuk menguji kualitas produk tersebut supaya dapat berguna di masyarakat, maka diperlukan penelitian untuk menguji kualitas produk tersebut. Pada penelitian ini dikembangkan video pembelajaran pada materi bangun ruang sisi datar kelas VIII Sekolah Menengah Pertama yang valid.

Dalam mengembangkan video pembelajaran matematika ini peneliti menggunakan tahap pengembangan 3D, yang telah dimodifikasi dari tahap pengembangan 4D, tahap ke empat dari tahapan 4D yaitu tahap penyebaran ke sekolah-sekolah tidak dilakukan, karena saat pandemi Covid-19 sekolah diliburkan, penyebaran hanya dilakukan melalui sosial media saja. tahap 3-D terdiri atas 3 (tiga) tahap (Sumaji, 2015) yaitu:

1. Tahap Define (Pendefenisian)

Tahap pendefenisian adalah menetapkan dan mendefenisikan kebutuhankebutuhan pembelajaran yang dilakukan dengan menganalisis dua aspek, yaitu analisis karakter siswa dan analisis kebutuhan siswa.

2. Tahap Design (Perancangan)

Tahap perancangan adalah tahap untuk melakukan perancangan produk yang akan dihasilkan untuk materi bangun ruang sisi datar kelas VIII Sekolah Menengah Pertama (SMP).

Kegiatan yang akan dilakukan adalah:

a. Pembuatan video pembelajaran menggunakan aplikasi GeoGebra yang berisi penjelasan mengenai materi bangun ruang sisi datar kelas VIII Sekolah Menengah Pertama

b. Memilih background dan gambar bangun ruang sisi datar yang dibuat pada aplikasi GeoGebra dengan warna yang baik dan mendesain semenarik mungkin, agar minat belajar peserta didik dapat tumbuh.

c. Pembuatan soal-soal latihan tentang materi bangun ruang sisi datar.

3. Tahap Development (Pengembangan)

Tahap pengembangan ini menghasilkan video pembelajaran matematika bangun ruang sisi datar dengan menggunakan aplikasi GeoGebra yang valid. Tahap ini terdiri dari 2 tahapan, yaitu: 
a. Validasi

Video pembelajaran matematika yang sudah direncanakan, dikonsultasiskan dan didiskusikan dengan beberapa orang validator. Kegiatan validasi dilakukan dengan mengisi lembar validasi sehingga diperoleh video pembelajaran matematika yang valid yang layak untuk disebarkan. Aspek yang divalidasi dapat dilihat pada Tabel 1.

Tabel 1. Aspek Validitas Penggunaan Video Pembelajaran

\begin{tabular}{|c|c|c|c|}
\hline No & Aspek Yang Dinilai & $\begin{array}{c}\text { Metode Pengumpulan } \\
\text { Data }\end{array}$ & Instrumen \\
\hline 1 & Didaktik & \multirow{4}{*}{$\begin{array}{c}\text { Memberikan Lembar } \\
\text { Validasi Kepada } \\
\text { Validator }\end{array}$} & \multirow{4}{*}{ Lembar Validasi } \\
\hline 2 & Isi & & \\
\hline 3 & Bahasa & & \\
\hline 4 & Tampilan & & \\
\hline
\end{tabular}

b. Tahap Revisi

Tahap revisi dilakukan apabila hasil penilaian dari validator ditemukan beberapa bagian yang perlu diperbaiki. Video pembelajaran matematika yang sudah direvisi diberikan kembali kepada validator untuk didiskusikan lebih lanjut apakah sudah valid sehingga layak digunakan.

\section{HASIL DAN PEMBAHASAN}

Ada beberapa tahap penelitian yang dilakukan, hasil dari tahap-tahap penelitian tersebut sebagai berikut:

1. Hasil Tahap Define (Pendefenisian)

Tahap pendefenisian adalah tahap awal yang harus dilakukan sebelum mengembangkan video pembelajaran matematika. Tahap ini sebagai landasan dalam mengembangkan video pembelajaran matematika yang dibutuhkan. Pada tahap ini dilakukan analisis siswa dan analisis kebutuhan siswa yang menjadi acuan pengembangan video pembelajaran matematika tersebut tepat dan efisien. Penjelasan dari analisis-analisis tersebut adalah sebagai berikut:

a. Analisis Karakteristik Siswa

Siswa kelas VIII Sekolah Menengah Pertama (SMP) menjadi subjek utama penelitian pengembangan video pembelajaran matematika ini. Analisis karakter siswa dilakukan melalui wawancara terhadap guru pengampu dan siswa kelas VIII. Dari hasil wawancara kepada guru dan murid kelas VIII SMP LMPD Suka Maju Rambah, materi bangun ruang sisi datar susah dipahami karena bentuk bangun yang tidak bisa mereka imajinasikan, mereka tidak bisa menebak apa-apa saja dan bagaimana bentuk dari unsur-unsur bangun ruang sisi datar tersebut. Melalui video pembelajaran matematika ini bisa mereka lihat dan pelajari agar mudah memahami bangun ruang sisi datar, karena di dalam video tersebut ditunjukkan apa-apa saja unsur-unsur dari 
bangun ruang sisi datar, dan ada juga penjelasan tentang jaring-jaring bangun ruang sisi datar serta penjelasan tentang luas dan volume bangun ruang sisi datar tersebut. Dari wawancara bersama guru dan beberapa siswa tersebut diperoleh bahwa video pembelajaran perlu digunakan untuk menunjang penyampaian materi untuk siswa saat pembelajaran.

b. Analisis Kebutuhan Siswa

Hasil analisis yang telah dilakukan menunjukkan bahwa siswa membutuhkan media pembelajaran yang bisa menumbuhkan minat belajar. Salah satu kemampuan yang harus dimiliki siswa untuk menghadapi tantangan global di zaman modern seperti sekarang perlu mengenalkan media pembelajaran multimedia berbasis komputer dan teknologi. Maka video pembelajaran matematika adalah salah satu media yang cocok diberikan.

2. Hasil Tahap Design (Perancangan)

Hasil rancangan video pembelajaran dapat dilihat pada link YouTube yang bertujuan agar video dapat diakses kapan saja dan dimana saja. Link YouTube untuk melihat isi video pembelajaran matematika tentang bangun ruang sisi datar Kubus yang membahas unsur-unsur kubus, luas dan volume kubus serta terdapat soal-soal latihan didalamnya adalah https://youtu.be/2GdLx2rMrsl dan link bangun ruang sisi datar Balok yang membahas unsur-unsur balok, luas dan volume balok serta terdapat soal-soal latihan didalamnya adalah https://youtu.be/VtfgZdc12YO.

3. Hasil Tahap Development (Pengembangan)

Kegiatan yang dilakukan setelah merancang video pembelajaran matematika menggunakan aplikasi GeoGebra pada materi bangun ruang sisi datar kelas VIII SMP ini adalah mengembangkan video pembelajaran tersebut untuk mengetahui validitas dari video pembelajaran tersebut. validasi video pembelajaran matematika ada 4 aspek yang divalidasi yaitu aspek didaktik, aspek isi, aspek bahasa dan aspek tampilan. Keempat aspek tersebut diberikan kepada validator untuk dinilai. Validasi dilakukan dengan dua orang validator video pembelajaran, yaitu dua orang dosen Pendidikan matematika.

Berdasarkan analisis dari keempat aspek penilaian validitas pengembangan video pembelajaran matematika menggunakan aplikasi GeoGebra di atas, maka diperoleh hasil validasi dari keseluruhan aspek. Hasil validasi pengembangan video pembelajaran matematika secara keseluruhan dapat dilihat pada Tabel 2 berikut:

Tabel 2. Hasil Validasi Keseluruhan Aspek

\begin{tabular}{ccccc}
\hline \multirow{2}{*}{ Validator } & \multicolumn{5}{c}{ Aspek Penilaian } \\
\cline { 2 - 5 } & Didaktik & Isi & Bahasa & Tampilan \\
\hline 1 & 3,3 & 3,7 & 4 & 3,7 \\
\hline 2 & 4 & 3,5 & 3 & 3,3 \\
\hline Rata-rata Aspek & 3,7 & 3,6 & 3,5 & 3,5 \\
\hline Rata Keseluruhan Aspek & \multicolumn{5}{c}{ Sangat Valid } \\
\hline Kategori & \multicolumn{5}{c}{}
\end{tabular}


Berdasarkan Tabel 2 diperoleh rata-rata hasil validasi untuk aspek didaktik adalah 3,7 dengan kategori Sangat Valid, rata-rata hasil validasi untuk aspek isi adalah 3,6 dengan kategori Sangat Valid, rata-rata hasil validasi untuk aspek bahasa adalah 3,5 dengan kategori Sangat Valid dan rata-rata hasil validasi untuk aspek tampilan adalah 3,5 dengan kategori Sangat Valid. Rata-rata keseluruhan aspek penilaian adalah 3,6 dengan kategori Sangat Valid. Maka dapat disimpulkan bahwa hasil validasi video pembelajaran matematika dengan menggunakan aplikasi GeoGebra yang dikembangkan adalah Sangat Valid.

Mengacu pada penelitian sebelumnya yang juga menggunakan video sebagai media dalam pembelajaran, seperti yang dilakukan oleh Saadah (2018) dengan judul "Pengembangan Media Pembelajaran Matematika Berbasis Video Animasi Dengan Menggunakan Adobe After Effect", yang juga memperoleh hasil yang cukup baik berupa penilaian oleh tenaga ahli dengan kategori "valid" dan "praktis" dengan nilai kualitatif B yang artinya media dapat digunakan dengan sedikit revisi. Berbeda dengan hasil penelitian yang peneliti lakukan, peneliti memperoleh hasil yang memuaskan, karena memperoleh hasil maksimal dari validator yang memberikan nilai dengan kategori "Sangat Valid". Nilai yang peneliti dapatkan sama dengan nilai yang diperoleh oleh peneliti lain yang bernama Wahyana (2018). Wahyana melakukan penelitian dengan judul "Pengembangan Video Pembelajaran Menggunakan Proshow pada Materi Satuan Ukur Dan Berat". Wahyana memperoleh hasil dari tenaga ahli dengan bentuk penilaian sebagai berikut: (a) Penilaian kelayakan oleh ahli materi diperoleh rata-rata skor sebesar $85,6 \%$ yang termasuk dalam kategori sangat layak; (b) Penilaian kelayakan oleh ahli media diperoleh ratarata skor sebesar 90,8\% yang termasuk dalam kategori "Sangat Layak".

Validasi yang dilakukan oleh validator bertujuan untuk mendapatkan kritik dan saran agar video pembelajaran yang dikembangkan oleh peneliti dapat dilakukan perbaikan dalam rangka menjadikan video pembelajaran yang berkualitas dan layak digunakan dalam proses pembelajaran matematika.

\section{KESIMPULAN DAN SARAN}

Kesimpulan penelitian ini berdasarkan uji validitas video pembelajaran matematika dengan menggunakan aplikasi GeoGebra pada materi bangun ruang sisi datar kelas VII Sekolah Menengah Pertama yang telah dilakukan pada dua orang validator adalah Sangat Valid.

Berdasarkan kesimpulan hasil penelitian dan pembahasan seperti yang telah disebutkan di atas, video pembelajaran matematika harus memiliki kelebihan yang cukup agar pengguna puas dalam menggunakannya. Video pembelajaran matematika yang dihasilkan peneliti masih memerlukan penyempurnaan, oleh karena itu dibutuhkan tindak lanjut dari peneliti lain untuk mengembangkan video pembelajaran ini guna meningkatkan kualitas video pembelajaran tersebut 


\section{DAFTAR PUSTAKA}

Aliviah, E. E. \& Rhudito, M.A. (2012). Efektifitas Pembelajaran dengan Program Geogebra Dibanding Pembelajaran Konvensional pada Topik Grafik Fungsi Kuadrat Kelas X SMA Pangudi Luhur Yogyakarta. Prosiding. Makalah dipresentasikan dalam Seminar Nasional Matematika dan Pendidikan Matematika. FMIPA UNY.

Daeng, I, T, M. dkk. (2017). Penggunaan Smartphone dalam Menunjang Aktivitas Perkuliahan oleh Mahasiswa Fispol Unsrat Manado. e-jurnal Acta Diuma. 6(1). $1-15$.

Efendi, I. (2018). Manfaat Komputer dalam Dunia Pendidikan. https://www.itjurnal.com/manfaat-komputer-dalam-dunia-pendidikan/\#comments, diakses 12 Juli 2020.

Jamil, F. (2019). Peranan Komputer Dalam Dunia Pendidikan.

Negari, H. (2012). Fungsi dan Manfaat Media Pembelajaran. https://herminegari.wordpress.com/perkuliahan/fungsi-dan-manfaat-mediapembelajaran/, diakses 4 Februari 2020.

Saadah, I. D. dkk. (2018). "Pengembangan Media Pembelajaran Matematika Berbasis Video Animasi dengan Menggunakan Adobe After Effect". (Skripsi, Fakultas IImu Tarbiyah dan Keguruan UIN Sunan Ampel Surabaya). Tidak diterbitkan.

Sugiyono. (2014). Metode Penelitian Kuantitatif, Kualitatif, dan R\&D. Bandung: Alfabeta.

Sumaji. (2015). Pengembangan Perangkat Pembelajaran Matematika dengan Model Pembelajaran Pemecahan salah untuk Meningkatkan Kemampuan Penalaran Matematis. Prosiding. Makalah dipresentasikan dalam Konferensi Nasional Penelitian Matematika dan Pembelajarannya. Universitas Muhammadiyah Surakarta.

Wahyana, R. dkk. (2018). Pengembangan Video Pembelajaran Menggunakan Proshow pada Materi Satuan Ukur dan Berat. Journal Template. 1 (2). 449-458. 